CELL BIOCHEMISTRY \& FUNCTION

\title{
Small animal models to understand pathogenesis of osteoarthritis and use of stem cells in cartilage regeneration.
}

\begin{tabular}{|c|l|}
\hline Journal: & Cell Biochemistry \& Function \\
\hline Manuscript ID & CBF-16-0103.R1 \\
\hline Diley - Manuscript type: & Review Article \\
\hline Complete List of Authors: & $\begin{array}{l}\text { Piombo, Virginia; Addenbrooke's Hospital, Division of Trauma and } \\
\text { Orthopaedic Surgery }\end{array}$ \\
\hline Keywords: & $\begin{array}{l}\text { Osteoarthritis, Stem Cells, Small animal models, Cartilage regeneration, } \\
\text { Synovial joint, Chondrocytes, Ligament transection, Joint surface defect }\end{array}$ \\
\hline & $\begin{array}{l}\text { Osteoarthritis (OA) is one of the most common diseases, which affect the } \\
\text { correct functionality of synovial joints and is characterized by articular } \\
\text { cartilage degradation. OA is one of the leading causes of mobility } \\
\text { impairment and symptoms include pain, swelling and stiffness of the joint. } \\
\text { Limitation in the treatment of OA is mostly due to the very limited } \\
\text { regenerative characteristic of articular cartilage once is damaged. Because } \\
\text { of the complex structure of the joint the more representative models to } \\
\text { study the different stages of OA are the in vivo models. Small animals are } \\
\text { of particular importance for mechanistic analysis to understand the } \\
\text { processes that affect cartilage degradation. They offer not only } \\
\text { reproducible and standardized models of surgery but also allow } \\
\text { manipulation of the genome in a tissue- and time-specific fashion. } \\
\text { Combination of joint injury techniques with the use of stem cells has been } \\
\text { shown to be an important tool for understanding the processes of cartilage } \\
\text { degradation and regeneration. Implementation of stem cells and small } \\
\text { animal models, as they develop OA similarly to humans, will help } \\
\text { researchers to find a solution that could prevent and ameliorate the } \\
\text { symptoms of OA and possibly avoid the need for surgery. }\end{array}$ \\
\hline & \begin{tabular}{|c|l}
\hline Abstract \\
\hline
\end{tabular} \\
\hline
\end{tabular}

\section{SCHOLARONE $^{\text {m }}$ \\ Manuscripts}


Small animal models to understand pathogenesis of osteoarthritis and use of stem cell in cartilage regeneration.

\section{Introduction}

Healthy hyaline articular cartilage is crucial for the proper functioning of the joint, providing a resilient and low friction surface for smooth articulation and capable of absorbing shocks due to mechanical loading ${ }^{1-4}$. Osteoarthritis (OA) is a joint disease characterized by enzymatic breakdown of proteoglycan and collagen and eventual loss of the cartilage of the articular surface This causes bone ends to grind against each other, impairing movement because of acute and chronic pain, swelling and stiffness of the joints and it can involve an immunological response ${ }^{5-7}$. In most cases treatment is restricted to perform joint replacement, partial or total ${ }^{8}$ and limitation in the treatment of OA is mostly due to the very limited regenerative characteristic of articular cartilage once it is damaged ${ }^{3,9}$. Recently the assumption that articular cartilage is a non-regenerative tissue has been challenged and new evidences suggest the presence of pre-chondrocytes, which could be used for regeneration and OA treatment.

Stem cells (SCs) are clonogenic and characterized by two main features: multi-potency (the ability to differentiate into different type of cells) and self-renewal (the ability of replenishing the SCs population $)^{10}$. As early as 1966 Friedenstein and colleagues showed that cells isolated from the bone marrow (BM) can differentiate into adipocytes, chondrocytes, osteoblasts and reticulocytes ${ }^{11}$. SCs in the joint have been identified in different tissues, not only in the stromal compartment of the bone marrow. The superficial zone has been hypothesized to harbour SCs and stem cell markers expression has been shown (Notch-1, Stro-1, and vascular cell adhesion-1) ${ }^{12,13}$. Notch-1 positive cells isolated from the superficial zone of the articular cartilage retain high colony-forming efficiency ${ }^{14}$, a characteristic of SCs, which was abolished once Notch signalling was inhibited ${ }^{15}$. Synovium might harbour SCs as the synovial membrane rapidly becomes hyperplastic when subjected to injuries or trauma ${ }^{16-18}$ and multi-potent SCs have been isolated from adult human synovium and expanded, showing limited senescence and maintaining the multi-lineage potency ${ }^{19}$. Another area that has been suggested to be a reservoir for SCs in terms of pre-chondrocytes is the groove of Ranvier, which was first described in 1873 and was shown to contain proliferating cells and express markers specific and typical for progenitors and SCs, such as Stro-1, Ptch1, Jagged-1, N-cadherin and FGFR3 20, 21 . Moreover, since 2003 several groups have demonstrated the ability of chondrocytes to generate in vitro multi-lineage potency and differentiate into chondrogenic, adipogenic and osteogenic lineage ${ }^{22-25}$. A schematic representation of where stem cell niches have been identified in the joint is depicted in Figure 1.

This review will particularly focus on the progress that has been done thanks to small animal models and on implementation of recruitment and injection of stem cell in different mouse models for the study of a therapy for OA.

\section{Why animal models are useful to understand OA}

The use of animal models is of critical importance to promote translational research to improve the options for OA prevention and progression. Animal models not only allow for 
evaluation of the entire osteochondral unit, but the in vivo situation is much more representative and complex compared to in vitro analysis only ${ }^{29,}{ }^{30}$. Large animals are more suitable for direct translational research, because of the great similarity in the structure of their articular cartilage and the mechanical load to humans. Smaller animals like rodents or rabbits are more useful for mechanistic and molecular analysis because of their relatively short generation time and the possibility of modifying their genome ${ }^{29,31-41}$. Small animal models for OA studies have been shown to share characteristics of the disease development common to human, such as cartilage degradation and proteoglycan depletion by proteinases ${ }^{42-47}$. Similarly to humans, different strains of mice develop spontaneous OA, with male mice having a higher incidence of cartilage degeneration compared to females, also shown in chemically induced and surgical models of OA ${ }^{44,48-52}$. Different mouse strains show different characteristics in term of response when $\mathrm{OA}$ is induced and therefore the appropriate genetic background should be chosen for investigating different OA processes. For example C57B1/6 spontaneously develop age-induced OA, but they are resistant to collagen-induce arthritis, to which DBA/1 mice are responsive ${ }^{53-55}$. Mouse models have contributed to identify different targets that could be modulated in order to protect articular cartilage from degradation. For example ablation of A disintegrin and metalloproteinase with thrombospondin motifs (ADAMTS-5) in mouse cartilage has been shown to protect against degradation after surgical induced $\mathrm{OA}^{44}$. In the same way, mice that secrete a form of Aggrecan (ACAN) resistant to aggrecanase-mediated cleavage were protected from OA development. This was not true for mice secreting a form of ACAN resistant to Matrix metalloproteinase (MMP)-mediated degradation, which developed a more severe form of OA compared to control mice, suggesting that a controlled balance of MMP-mediated degradation could be necessary for cartilage homeostasis ${ }^{56}$.

At present there are different models for studying $\mathrm{OA}$ in mice: age-induced $\mathrm{OA}$ can be observed in STR/ort mouse ${ }^{46}$ and $\mathrm{C} 57 \mathrm{Bl} / 6$ mice $^{54}$ and also in gene manipulated mice such as Dell ${ }^{57}$. However, age-induced OA requires a long waiting time before even being able to study the defects and genetically altered mouse models can exhibit other cartilage disorders like chondrodysplasia even in the absence of surgical or stress induced-defects ${ }^{46,58}$. During the past years researchers started to improve and standardize different models, which are more representative of secondary or post-traumatic OA (PTOA) and involve both surgical and mechanical insult to the joint.

\section{Different type of injury to understand different mechanistic aspects of $O A$ and repair: Ligament resection and meniscectomy}

Kamekura et al. have recently compared four different surgical models of OA including anterior cruciate ligament transection (ACLT), complete medial meniscectomy (MM), posterior cruciate and patellar ligament transection, as well as medial collateral ligament transection ${ }^{59}$. Glasson et al. compared two different surgical techniques such as ACLT and displacement of the medial meniscus (DMM). Both Kamekura and Glasson observed in the ACLT model mild OA in the anterior region of the joint and moderate to severe OA in the central weight-bearing region 59,60 .

In the DMM model the mice developed mild to moderate OA and, although the severity of the lesions increased over time, posterior erosion of the tibial plateau, as for the ACLT model 
was never observed. Also neo-condrogenesis was significant in the ACLT model while absent in the DMM, as well as free cells in the synovial cavity ${ }^{60}$. The DMM model appears to be more similar to the slow degradation of OA in human compared to the ACLT model. Moreover it has been successfully employed in different strains of KO mice to understand the progression of $\mathrm{OA}$ and the role of those genes in the process, such as Adamts-5 and Interleukin-1b $(I l-1 b)^{44,53}$. Deletion of Adamts-5 has been shown to have a protective effect against $\mathrm{OA}$ development, in contrast to $M M P 13$, whose ablation had negative effects on the progression of $\mathrm{OA}$, suggesting that a balance between degradation and regeneration is crucial in maintaining cartilage integrity ${ }^{44,61}$.

Clements et al. ${ }^{43}$ analyzed a model similar to the one proposed by Glasson ${ }^{60}$ with the difference that in addition to the resection of the medial ligament they performed partial meniscectomy. They performed this surgery to analyze a KO model lacking different enzymes and factors that play crucial roles in the development of OA, like $I l-1 b$ and stromelysin. Surprisingly all the models analyzed developed accelerated cartilage destruction 4 weeks after surgery, suggesting that a controlled balance of degradation and regeneration is important to maintain cartilage integrity. The combination of ligament transection with meniscectomy results in a more severe late OA phenotype compared to ligament resection alone, with formation of osteophytes, and a slightly accelerated degradation of cartilage during the early phases after surgery ${ }^{43,60}$.

\section{Non-invasive mouse models of PTOA}

A variation to the surgical models of PTOA, in which an external mechanical load is applied, has been developed in order to recreate aseptic injury and avoiding the problematic related to trauma derived from invasive surgical procedures. Furman et al. were the first to describe a non-invasive mouse model of PTOA that simulates a severe injury comparable to collision impacts where high-energy forces applied to the joint generates an intraarticular fracture (IAF) of the tibia ${ }^{62}$. This results in severe damage to the articular cartilage and subchondral bone, with bone marrow infiltration into the synovial cavity due to dislodgement of the articular surface. Progressive loss of proteoglycan ended in complete loss of articular cartilage was observed accompanied by a thickening of the subchondral bone of both tibia and femur. However high variability in joint inflammation and levels of joint degradation was observed in different animals ${ }^{63}$.

Ward et al. compared the results of IAF after PTOA in two different mouse strains, $\mathrm{MRL} / \mathrm{MpJ}$ mice and $\mathrm{C} 57 \mathrm{Bl} / 6$, and analyzed according to their different regenerative properties, the first being known as a good healer and the second for his very poor tissue regeneration ${ }^{64}$. Analysis revealed that $\mathrm{MRL} / \mathrm{MpJ}$ mice had little changes in bone density, subchondral bone thickness, and cartilage degeneration. This was associated with reduced systemic inflammation as well of the joint compared to $\mathrm{C} 57 \mathrm{Bl} / 6$ mice, as shown by lower levels of TNF $\alpha$ and IL- $1 \alpha$ and IL-1 $\beta$ at gene expression and protein level in different joint tissues. Moreover, macrophage chemokines release and infiltration of the synovial tissue was increased in $\mathrm{C} 57 \mathrm{~B} 1 / 6$ compared to MRL/MpJ mice ${ }^{65}$.

Diekman et al. investigated the use of stem cell therapy in $\mathrm{C} 57 \mathrm{Bl} / 6$ mice with the IAF method by injecting SCs isolated from either MRL/MpJ or C57Bl/6 mice at the site of the defect ${ }^{66}$. They could observe a trophic effect with SCs derived from both MRL/MpJ and 
C57B1/6, which prevented PTOA 8 weeks post injury, as shown by other authors with surgical models of $\mathrm{OA}^{67}$, although it could not inhibit inflammation and macrophage invasion of the synovium ${ }^{68}$. Christiansen et al. described the use of a single heavy load compression of the tibia in young $\mathrm{C} 57 \mathrm{BL} / 6$ mice to mimic acute joint injury in human ${ }^{69}$, similarly to experiments performed in rabbits ${ }^{70}$. This method results in rupture of the ACL, trabecular bone loss of femur and tibia, osteophytes formation, breakdown and degeneration of articular cartilage with loss of proteoglycan and chondrocyte apoptosis.

Cyclic tibial compression was used first by Poulet and colleagues to induce cartilage degeneration in CBA mice ${ }^{71}$ and they could observe proteoglycan loss, lesion of the articular cartilage on the lateral side and a general increased severity of the lesion after 3 weeks of loading. This model was used on the STR/Ort mouse strain, which spontaneously develop OA to show that external injury did not influenced OA development in this mouse background and therefore genetic predisposition is not related to mechanical trauma susceptibility $^{72}$. Onur et al. ${ }^{73}$ compared cyclic compression with and without rupture of the ACL in FVB mice and the results were consistent with previous study ${ }^{74}$, where ACL injury is responsible for displacement of the structures in the joint and development of a severe OA phenotype. Only animals with ACL rupture showed inflammation of the synovium and osteophyte formation. Progress of degradation can be accelerated with additional loading cycles ${ }^{73,74}$, but a less severe type of injury cannot be achieved with this model. In addition, similarly to the DMM model, cartilage degeneration is due to an increased instability of the joint structure due to the injury to the ACL, rather than a direct effect on the articular cartilage as for the cyclic tibial compression without ACL rupture. However, while the DMM surgery induces a mild to moderate severity of OA, cyclic compression with rupture of the ACL generate a severe degradation.

\section{Cartilage degeneration and recruitment of SC: Subchondral drilling and joint superficial defects.}

At the present time one of the common surgical options in the clinic to treat small defects of articular cartilage involves stimulation of bone marrow SCs to migrate and to generate scar tissue over the lesion. This is achieved by micro-fracture performed by drilling through the articular layers into the marrow cavity to allow stromal SCs to migrate and to invade the newly formed defect, generating a clot, which spontaneously differentiates into fibrocartilage. This procedure is relatively low cost and simple ${ }^{75,76}$ but the level of repair that can be observed depends on different factors, like the size of the lesion and gender, age and body mass index (BMI) of the patients ${ }^{75-77}$. Montoya et al. recently induced micro-fracture in rabbits and evaluated histologically and immunohistochemically the scar formation ${ }^{78}$. The scar tissue lacked staining for proteoglycan-rich matrix (SafraninO and ACAN) as well as Collagen (COL)1 and 2. These results were consistent with previous reports and indicated that whilst the micro-fracture technique is a good system to repair the articular surface the scar tissue does not present the typical characteristics of hyaline articular cartilage ${ }^{78}$.

A more extensive study on the micro-fracture model has been recently performed by Matsuoka and colleagues in a mouse model ${ }^{79}$. They analyzed the outcome of this technique on $\mathrm{C} 57 \mathrm{Bl} / 6$ mice when surgery was performed at different ages ${ }^{79-81}$. The $\mathrm{C} 57 \mathrm{Bl} / 6$ strain is very well known for its poor ability for cartilage repair and the type of repair observed when 
surgery was performed at young or juvenile stages differed greatly from that observed in adult mice. As expected adult $\mathrm{C} 57 \mathrm{Bl} / 6$ mice showed poor cartilage repair, while young and juvenile mice showed better cartilage repair compared with that of adult subgroup ${ }^{79}$. This result is importantly showing that the regenerative ability of young and juvenile C57B1/6 mice is comparable to very good healing strains such as MRL/MpJ and DBA/1 mice ${ }^{80,82}$. As different strains show different regeneration characteristics ${ }^{83,84}$, a previous study compared the healing abilities of MRL/MpJ, the so-called "super-healer" ${ }^{85}$ with $\mathrm{C} 57 \mathrm{Bl} / 6$ strain ${ }^{86-88}$. Fitzgerald et al. induced an articular cartilage defect in those two different mouse strains. The repair site in MRL/MpJ mice was populated by round chondrogenic cells, which secreted a proteoglycan-rich matrix. Collagen was also present in the newly repaired lesion and resembled the surrounding healthy cartilage. In contrast, the quality of the repair tissue in the C57B1/6 control mice was poor, with very few chondrocytes and a fibrous cartilage lacking both proteoglycan and collagen ${ }^{81}$.

These results strongly support the existence of a certain cell type, which can promote good healing of articular defects. Although it might be argued that results derived from these types of studies cannot be translated to the clinic, as good repair is observed only in young mice while patients with articular defects are usually adults, they still can be very useful to identify the best type of cell to promote repair. Young mice offer the best model to study the mechanisms of repair as they were able to develop hyaline cartilage, while juveniles formed fibrocartilage and adults showed poor cartilage repair ${ }^{79}$.

Similarly to Fitzgerald et al. another group compared the effect of superficial joint defects in two mouse strains with different healing abilities: DBA/ 1 and C57BL/ $6{ }^{80}$. The lesion that they generated was highly standardized, choosing a specific site of the femur where cartilage thickness is uniform and accessible after patellar dislocation. The authors created a defect that was deeper than the full thickness of the cartilage and would run along the center of the patellar groove, ensured by the use of a glass bead together with the needle. As also observed by Kamekura et al. ${ }^{59}$ the younger mice DBA/1 healed the surface defect while the C57BL/6 did not and developed in addition secondary OA. Different repair in different strain is due to different regulation of cell viability and matrix remodeling. When the defect was induced in DBA/1 aged mice, they did not show repair of the lesion either, confirming that the age of the animals when the lesion occurs is a crucial factor that affects the repair ${ }^{80}$.

Regeneration after insult: Injection of SCs in the articular cartilage at the site of injury. Brittberg et al. have first reported the implementation of autologous transplantation of chondrocytes derived from an arthroscopically harvested healthy area of the same patient into an area of lesion or damaged cartilage ${ }^{89}$. Cells were first expanded in vitro and then injected in solution over the damaged area, previously covered with periosteum. Follow-up showed positive outcome in all patients with the formation of hyaline cartilage at the site of the transplant ${ }^{89}$. Some issues presented themselves with this technique: of particular importance were the problems of dedifferentiation of chondrocytes into fibroblast-like cells after monolayer culture and difficulties in the positioning of the grafted cells. Therefore different scaffolds with different collagen, polyglycolic/polylactic acid, hyaluronic acid and fibrin gel compositions have been engineered to achieve a more uniform and reproducible repair of the lesion ${ }^{90-94}$. Follow up of these patient cohorts has shown successful regeneration and 
integration of the graft and healthy cartilage appearance ${ }^{95-99}$. Although the general outcome of the repair was positive, the newly formed cartilage did not entirely resemble the native articular cartilage. ${ }^{100-102}$.

During the past few years stromal SCs have become the best candidate for isolation, rapid expansion and differentiation into chondrocytes ${ }^{103}$. Bone marrow and umbilical cordderived SCs have been widely used in the effort of regenerate hyaline cartilage in vitro ${ }^{104}$. Although the use of scaffolds to promote and improve the generation of repair cartilage in vivo showed positive outcome in various animal models, they have not been suggested for the use in human because of possible side effects ${ }^{105}$. Another option is the implantation of small spherical aggregates of chondrocytes, whose structure resemble that of native cartilage ${ }^{106}$. This approach eliminates both the use of scaffolds and the associated problems, such as toxicity, immunogenicity, differentiation due to mechanical strain forces 107,108 and the problem of ECM degradation in the repair tissue ${ }^{109,110 .}$

Further development in the use of pellet culture has been made using microspheres to induce chondrogenesis in human mesenchymal stem cells (hMSC) ${ }^{111,112}$. Microspheres were able to release continuously TGFb3, allowing its availability in situ for hMSCs to differentiate and at the same time avoiding side effects of scaffolds, such as osteophyte formation and inflammation ${ }^{113}$. A collagenase-induced model of OA was treated with implanted hMSCs and differentiation occurred only when TGFb3 was present, with both mouse and human cells taking part to the formation of repair cartilage. The implementation of a technology such as the microsphere could be useful to deliver differentiating agents with only a single implantation, avoiding the need for repeated injections. It is important the fact that cartilage formation from MSCs could develop also in the pathological environment of OA, because not only MSCs differentiated into chondrocytes but they also confirmed a trophic effect on the host cartilage ${ }^{114-116}$.

Horie et al. performed an experiment of xenotransplantation of hMSCs into rat meniscus and they observed that they promoted meniscal regeneration with synthesis of rat-COL2 although only a few of the human cells actually engrafted in the host tissue and differentiated. Also hMSCs showed a protective effect on the cartilage, demonstrated by reduced OA of the tibia when compared to the control knees ${ }^{117}$. Therefore it appears that the effect of MSCs is not only limited to differentiation into chondrocytes but they can play an important role in immunomodulation and have a trophic effect on the surrounding tissue ${ }^{118}$. MSCsconditioned medium is rich in factors with anti-inflammatory and anti-catabolic activity, which could modulate the gene expression of synovial cells and cartilage. Gene expression changes due to MSCs were not only limited to genes related to inflammation (IL-1b, IL-1RA, SOCS1) but also to matrix degradation (MMP1, MMP13 and ADAMTS-5). Therefore implanting MSCs in an OA-affected joint could promote and ameliorate the healing process, providing a valid alternative to replacement surgery in terms of less invasive and autologous treatment.

Mak et al. isolated bone marrow derived MSCs from two different strains of mice (MRL/MpJ and $\mathrm{C} 57 \mathrm{Bl} / 6$ ) in order to treat lesions of the articular cartilage. MRL/MpJ-derived MSCs were able to take part in the repair of the cartilage, a phenomena not observed with cells derived from the $\mathrm{C} 57 \mathrm{Bl} / 6$. In both $\mathrm{MRL} / \mathrm{MpJ}$ - and $\mathrm{C} 57 \mathrm{Bl} / 6$-derived cells, the injection of MSCs showed an improved outcome compared to the non-injected controls. Nevertheless 
C57B1/6-derived cells were not able to take part in the repair. It should also be noted that whilst MRL/MpJ-derived cells were able to colonize the site of repair first, they were not integral to the repair tissue at later stages, suggesting that MRL/MpJ-MSCs can take part in the early stages of the wound healing process and facilitate the higher quality repair observed in these mouse models ${ }^{67}$.

\section{Conclusions}

Articular cartilage is a tissue with an extremely reduced ability to regenerate on its own. Although the presence of cartilage progenitors and SCs has been shown by many different studies $12,13,19-21,26-28$ the challenge still remain to understand which cell type is actually a stem cell and how to induce them toward the best pathway for cartilage repair. Animal studies are important in elucidating the mechanisms that regulate cell differentiation in an in vivo environment.

Most surgical and mechanical models might not be considered comparable to the spontaneous development of $\mathrm{OA}$ in human patients as the lesion is induced and degradation is not naturally occurring. These models are considered more representative of trauma-induced OA, but still they allow the combination of generating a cartilage defect together with the possibility of activating and inactivating genes in vivo in a time and tissue specific manner ${ }^{32-}$ ${ }^{41}$. Different techniques to induce OA are summarized in Table 1, together with the severity of OA each of them generates. Also a schematic representation of the knee joint with the surgery location of different techniques is depicted in Figure2. Different levels of OA can be achieved with different techniques and therefore each method can be chosen based on of the particular OA characteristics that need to be investigated. The severe and moderate models could be useful to evaluate osteochondral defects that involve cartilage as well as bone, like for example formation of osteophytes. The moderate models are characterized by a slower and more constant cartilage degradation, allowing researcher to follow OA development from very early stages, suggesting their use for mechanistic analysis of the processes involved. These methods provide researchers with powerful tools to better understand chondrocytes and their precursor behavior in response to stress and to better understand the possible repair and what influence different genes might have in the process ${ }^{23,63-74,119-121}$. 


\section{References}

1. Buckwalter JA, Mankin HJ. Articular cartilage: tissue design and chondrocyte-matrix interactions. Instructional course lectures 1998; 47: 477-486.

2. Hunziker EB, Michel M, Studer D. Ultrastructure of adult human articular cartilage matrix after cryotechnical processing. Microscopy research and technique 1997; 37: 271-284. $\quad$ DOI: $\quad 10.1002 /($ SICI)1097-0029(19970515)37:4<271::AIDJEMT3>3.0.CO;2-O

3. Hunziker EB, Quinn TM, Hauselmann HJ. Quantitative structural organization of normal adult human articular cartilage. Osteoarthritis and cartilage / OARS, Osteoarthritis Research Society 2002; 10: 564-572.

4. O'Driscoll SW. The healing and regeneration of articular cartilage. The Journal of bone and joint surgery American volume 1998; 80: 1795-1812.

5. Koopman W. Editor, Arthritis and Allied Conditions: A Textbook of Rheumatology.; Williams \& Wilkins: Baltimore,, 1997; 1985-2011.

6. Resnick D. Patterns of migration of the femoral head in osteoarthritis of the hip. Roentgenographic-pathologic correlation and comparison with rheumatoid arthritis. The American journal of roentgenology, radium therapy, and nuclear medicine 1975; 124: $62-74$.

7. Heinegard D, Saxne T. The role of the cartilage matrix in osteoarthritis. Nature reviews Rheumatology 2011; 7: 50-56. DOI: 10.1038/nrrheum.2010.198

8. $\quad$ http://www.nhs.uk/conditions/Osteoarthritis/Pages/treatment.aspx [17 May 2016]

9. Caplan AI, Goldberg VM. Principles of tissue engineered regeneration of skeletal tissues. Clinical orthopaedics and related research 1999: S12-16.

10. Weissman IL. Stem cells: units of development, units of regeneration, and units in evolution. Cell 2000; 100: 157-168.

11. Friedenstein AJ, Piatetzky S, II, Petrakova KV. Osteogenesis in transplants of bone marrow cells. Journal of embryology and experimental morphology 1966; 16: 381390.

12. Grogan SP, Miyaki S, Asahara H, D'Lima DD, Lotz MK. Mesenchymal progenitor cell markers in human articular cartilage: normal distribution and changes in osteoarthritis. Arthritis research \& therapy 2009; 11: R85. DOI: 10.1186/ar2719

13. Henriksson H, Thornemo M, Karlsson C, Hagg O, Junevik K, Lindahl A, Brisby H. Identification of cell proliferation zones, progenitor cells and a potential stem cell niche in the intervertebral disc region: a study in four species. Spine 2009; 34: 22782287. DOI: 10.1097/BRS.0b013e3181a95ad2

14. Hayes AJ, Dowthwaite GP, Webster SV, Archer CW. The distribution of Notch receptors and their ligands during articular cartilage development. Journal of anatomy 2003; 202: 495-502.

15. Dowthwaite GP, Bishop JC, Redman SN, Khan IM, Rooney P, Evans DJ, Haughton L, Bayram Z, Boyer S, Thomson B, Wolfe MS, Archer CW. The surface of articular cartilage contains a progenitor cell population. Journal of cell science 2004; 117: 889897. DOI: $10.1242 /$ jcs.00912

16. Amizuka N, Warshawsky H, Henderson JE, Goltzman D, Karaplis AC. Parathyroid hormone-related peptide-depleted mice show abnormal epiphyseal cartilage development and altered endochondral bone formation. The Journal of cell biology 1994; 126: 1611-1623.

17. Pessler F, Dai L, Diaz-Torne C, Gomez-Vaquero C, Paessler ME, Zheng DH, Einhorn E, Range U, Scanzello C, Schumacher HR. The synovitis of "non-inflammatory" 
orthopaedic arthropathies: a quantitative histological and immunohistochemical analysis. Annals of the rheumatic diseases 2008; 67: 1184-1187. DOI: 10.1136/ard.2008.087775

18. Buckley CD, Filer A, Haworth O, Parsonage G, Salmon M. Defining a role for fibroblasts in the persistence of chronic inflammatory joint disease. Annals of the rheumatic diseases 2004; 63 Suppl 2: ii92-ii95. DOI: 10.1136/ard.2004.028332

19. Karystinou A, Dell'Accio F, Kurth TB, Wackerhage H, Khan IM, Archer CW, Jones EA, Mitsiadis TA, De Bari C. Distinct mesenchymal progenitor cell subsets in the adult human synovium. Rheumatology 2009; 48: 1057-1064. DOI: 10.1093/rheumatology/kep192

20. Karlsson C, Thornemo M, Henriksson HB, Lindahl A. Identification of a stem cell niche in the zone of Ranvier within the knee joint. Journal of anatomy 2009; 215: 355-363. DOI: 10.1111/j.1469-7580.2009.01115.x

21. Shapiro F, Holtrop ME, Glimcher MJ. Organization and cellular biology of the perichondrial ossification groove of ranvier: a morphological study in rabbits. The Journal of bone and joint surgery American volume 1977; 59: 703-723.

22. Barbero A, Ploegert S, Heberer M, Martin I. Plasticity of clonal populations of dedifferentiated adult human articular chondrocytes. Arthritis and rheumatism 2003; 48: 1315-1325. DOI: 10.1002/art.10950

23. Dell'Accio F, De Bari C, Luyten FP. Microenvironment and phenotypic stability specify tissue formation by human articular cartilage-derived cells in vivo. Experimental cell research 2003; 287: 16-27.

24. Tallheden T, Dennis JE, Lennon DP, Sjogren-Jansson E, Caplan AI, Lindahl A. Phenotypic plasticity of human articular chondrocytes. The Journal of bone and joint surgery American volume 2003; 85-A Suppl 2: 93-100.

25. Thornemo M, Tallheden T, Sjogren Jansson E, Larsson A, Lovstedt K, Nannmark U, Brittberg M, Lindahl A. Clonal populations of chondrocytes with progenitor properties identified within human articular cartilage. Cells, tissues, organs 2005; 180: 141-150. DOI: $10.1159 / 000088242$

26. Bianco P, Robey PG, Saggio I, Riminucci M. "Mesenchymal" stem cells in human bone marrow (skeletal stem cells): a critical discussion of their nature, identity, and significance in incurable skeletal disease. Human gene therapy 2010; 21: 1057-1066. DOI: 10.1089/hum.2010.136

27. Caplan AI. Mesenchymal stem cells. Journal of orthopaedic research : official publication of the Orthopaedic Research Society 1991; 9: 641-650. DOI: 10.1002/jor.1100090504

28. Horwitz EM, Le Blanc K, Dominici M, Mueller I, Slaper-Cortenbach I, Marini FC, Deans RJ, Krause DS, Keating A. Clarification of the nomenclature for MSC: The International Society for Cellular Therapy position statement. Cytotherapy 2005; 7: 393-395. DOI: 10.1080/14653240500319234

29. Orth P, Meyer HL, Goebel L, Eldracher M, Ong MF, Cucchiarini M, Madry H. Improved repair of chondral and osteochondral defects in the ovine trochlea compared with the medial condyle. Journal of orthopaedic research : official publication of the Orthopaedic Research Society 2013; 31: 1772-1779. DOI: 10.1002/jor.22418

30. Orth P, Zurakowski D, Wincheringer D, Madry H. Reliability, reproducibility, and validation of five major histological scoring systems for experimental articular cartilage repair in the rabbit model. Tissue engineering Part C, Methods 2012; 18: 329-339. DOI: 10.1089/ten.TEC.2011.0462 
31. Cook JL, Hung CT, Kuroki K, Stoker AM, Cook CR, Pfeiffer FM, Sherman SL, Stannard JP. Animal models of cartilage repair. Bone \& joint research 2014; 3: 89-94. DOI: $10.1302 / 2046-3758.34 .2000238$

32. Thomas KR, Folger KR, Capecchi MR. High frequency targeting of genes to specific sites in the mammalian genome. Cell 1986; 44: 419-428.

33. Thomas KR, Capecchi MR. Site-directed mutagenesis by gene targeting in mouse embryo-derived stem cells. Cell 1987; 51: 503-512.

34. Sauer B. Functional expression of the cre-lox site-specific recombination system in the yeast Saccharomyces cerevisiae. Molecular and cellular biology 1987; 7: 20872096.

35. Sauer B, Henderson N. Site-specific DNA recombination in mammalian cells by the Cre recombinase of bacteriophage P1. Proceedings of the National Academy of Sciences of the United States of America 1988; 85: 5166-5170.

36. Orban PC, Chui D, Marth JD. Tissue- and site-specific DNA recombination in transgenic mice. Proceedings of the National Academy of Sciences of the United States of America 1992; 89: 6861-6865.

37. Gu H, Zou YR, Rajewsky K. Independent control of immunoglobulin switch recombination at individual switch regions evidenced through Cre-loxP-mediated gene targeting. Cell 1993; 73: 1155-1164.

38. Turan S, Galla M, Ernst E, Qiao J, Voelkel C, Schiedlmeier B, Zehe C, Bode J. Recombinase-mediated cassette exchange (RMCE): traditional concepts and current challenges. Journal of molecular biology 2011; 407: 193-221. DOI: 10.1016/j.jmb.2011.01.004

39. Miller JC, Tan S, Qiao G, Barlow KA, Wang J, Xia DF, Meng X, Paschon DE, Leung E, Hinkley SJ, Dulay GP, Hua KL, Ankoudinova I, Cost GJ, Urnov FD, Zhang HS, Holmes MC, Zhang L, Gregory PD, Rebar EJ. A TALE nuclease architecture for efficient genome editing. Nature biotechnology 2011; 29: 143-148. DOI: $10.1038 /$ nbt. 1755

40. Cong L, Ran FA, Cox D, Lin S, Barretto R, Habib N, Hsu PD, Wu X, Jiang W, Marraffini LA, Zhang F. Multiplex genome engineering using CRISPR/Cas systems. Science 2013; 339: 819-823. DOI: 10.1126/science. 1231143

41. Zhang H, Zhang J, Wei P, Zhang B, Gou F, Feng Z, Mao Y, Yang L, Xu N, Zhu JK. The CRISPR/Cas9 system produces specific and homozygous targeted gene editing in rice in one generation. Plant biotechnology journal 2014; 12: 797-807. DOI: 10.1111/pbi. 12200

42. Chambers MG, Cox L, Chong L, Suri N, Cover P, Bayliss MT, Mason RM. Matrix metalloproteinases and aggrecanases cleave aggrecan in different zones of normal cartilage but colocalize in the development of osteoarthritic lesions in STR/ort mice. Arthritis and rheumatism 2001; 44: 1455-1465. DOI: 10.1002/15290131(200106)44:6<1455::AID-ART241>3.0.CO;2-J

43. Clements KM, Price JS, Chambers MG, Visco DM, Poole AR, Mason RM. Gene deletion of either interleukin-1beta, interleukin-1beta-converting enzyme, inducible nitric oxide synthase, or stromelysin 1 accelerates the development of knee osteoarthritis in mice after surgical transection of the medial collateral ligament and partial medial meniscectomy. Arthritis and rheumatism 2003; 48: 3452-3463. DOI: 10.1002/art.11355

44. Glasson SS, Askew R, Sheppard B, Carito B, Blanchet T, Ma HL, Flannery CR, Peluso D, Kanki K, Yang Z, Majumdar MK, Morris EA. Deletion of active ADAMTS5 prevents cartilage degradation in a murine model of osteoarthritis. Nature 2005; 434: 644-648. DOI: 10.1038/nature03369 
45. Guerne PA, Carson DA, Lotz M. IL-6 production by human articular chondrocytes. Modulation of its synthesis by cytokines, growth factors, and hormones in vitro. $J$ Immunol 1990; 144: 499-505.

46. Mason RM, Chambers MG, Flannelly J, Gaffen JD, Dudhia J, Bayliss MT. The STR/ort mouse and its use as a model of osteoarthritis. Osteoarthritis and cartilage / OARS, Osteoarthritis Research Society 2001; 9: 85-91. DOI: 10.1053/joca.2000.0363

47. Price JS, Chambers MG, Poole AR, Fradin A, Mason RM. Comparison of collagenase-cleaved articular cartilage collagen in mice in the naturally occurring STR/ort model of osteoarthritis and in collagen-induced arthritis. Osteoarthritis and cartilage / OARS, Osteoarthritis Research Society 2002; 10: 172-179. DOI: 10.1053/joca.2001.0500

48. Silberberg R, Silberberg M. Age Factor in the Response of Mice to the Administration of Radioactive Iodine (I-131) and Propylthiouracil (Ptu). Gerontologia 1963; 49: 140-149.

49. Silberberg R, Silberberg M, Feir D. Occurrence of Long-Spacing (Fls) Collagen in the Articular Cartilage of the Mouse. Pathologia et microbiologia 1963; 26: 779-783.

50. Sokoloff L. Natural history of degenerative joint disease in small laboratory animals. I. Pathological anatomy of degenerative joint disease in mice. AMA archives of pathology 1956; 62: 118-128.

51. Glasson SS, Askew R, Sheppard B, Carito BA, Blanchet T, Ma HL, Flannery CR, Kanki K, Wang E, Peluso D, Yang Z, Majumdar MK, Morris EA. Characterization of and osteoarthritis susceptibility in ADAMTS-4-knockout mice. Arthritis and rheumatism 2004; 50: 2547-2558. DOI: 10.1002/art.20558

52. Ma HL, Blanchet TJ, Peluso D, Hopkins B, Morris EA, Glasson SS. Osteoarthritis severity is sex dependent in a surgical mouse model. Osteoarthritis and cartilage/ OARS, Osteoarthritis Research Society 2007; 15: 695-700. DOI: 10.1016/j.joca.2006.11.005

53. Glasson SS. In vivo osteoarthritis target validation utilizing genetically-modified mice. Current drug targets 2007; 8: 367-376.

54. Wilhelmi G, Faust R. Suitability of the C57 black mouse as an experimental animal for the study of skeletal changes due to ageing, with special reference to osteoarthrosis and its response to tribenoside. Pharmacology 1976; 14: 289-296.

55. Wooley PH, Luthra HS, Stuart JM, David CS. Type II collagen-induced arthritis in mice. I. Major histocompatibility complex (I region) linkage and antibody correlates. The Journal of experimental medicine 1981; 154: 688-700.

56. Page-McCaw A, Ewald AJ, Werb Z. Matrix metalloproteinases and the regulation of tissue remodelling. Nature reviews Molecular cell biology 2007; 8: 221-233. DOI: $10.1038 / \mathrm{nrm} 2125$

57. Saamanen AK, Salminen HJ, Dean PB, De Crombrugghe B, Vuorio EI, Metsaranta MP. Osteoarthritis-like lesions in transgenic mice harboring a small deletion mutation in type II collagen gene. Osteoarthritis and cartilage / OARS, Osteoarthritis Research Society 2000; 8: 248-257. DOI: 10.1053/joca.2000.0298

58. Glasson SS, Trubetskoy OV, Harlan PM, Chavarria AE, Haimes HB, Jimenez PA. Blotchy mice: a model of osteoarthritis associated with a metabolic defect. Osteoarthritis and cartilage / OARS, Osteoarthritis Research Society 1996; 4: 209212.

59. Kamekura S, Hoshi K, Shimoaka T, Chung U, Chikuda H, Yamada T, Uchida M, Ogata N, Seichi A, Nakamura K, Kawaguchi H. Osteoarthritis development in novel experimental mouse models induced by knee joint instability. Osteoarthritis and 
cartilage / OARS, Osteoarthritis Research Society 2005; 13: 632-641. DOI: 10.1016/j.joca.2005.03.004

60. Glasson SS, Blanchet TJ, Morris EA. The surgical destabilization of the medial meniscus (DMM) model of osteoarthritis in the 129/SvEv mouse. Osteoarthritis and cartilage / OARS, Osteoarthritis Research Society 2007; 15: 1061-1069. DOI: 10.1016/j.joca.2007.03.006

61. Little CB, Barai A, Burkhardt D, Smith SM, Fosang AJ, Werb Z, Shah M, Thompson EW. Matrix metalloproteinase 13-deficient mice are resistant to osteoarthritic cartilage erosion but not chondrocyte hypertrophy or osteophyte development. Arthritis and rheumatism 2009; 60: 3723-3733. DOI: 10.1002/art.25002

62. Furman BD, Strand J, Hembree WC, Ward BD, Guilak F, Olson SA. Joint degeneration following closed intraarticular fracture in the mouse knee: a model of posttraumatic arthritis. Journal of orthopaedic research : official publication of the Orthopaedic Research Society 2007; 25: 578-592. DOI: 10.1002/jor.20331

63. Lewis JS, Hembree WC, Furman BD, Tippets L, Cattel D, Huebner JL, Little D, DeFrate LE, Kraus VB, Guilak F, Olson SA. Acute joint pathology and synovial inflammation is associated with increased intra-articular fracture severity in the mouse knee. Osteoarthritis and cartilage / OARS, Osteoarthritis Research Society 2011; 19: 864-873. DOI: 10.1016/j.joca.2011.04.011

64. Ward BD, Furman BD, Huebner JL, Kraus VB, Guilak F, Olson SA. Absence of posttraumatic arthritis following intraarticular fracture in the $\mathrm{MRL} / \mathrm{MpJ}$ mouse. Arthritis and rheumatism 2008; 58: 744-753. DOI: 10.1002/art.23288

65. Lewis JS, Furman BD, Zeitler E, Huebner JL, Kraus VB, Guilak F, Olson SA. Genetic and cellular evidence of decreased inflammation associated with reduced incidence of posttraumatic arthritis in MRL/MpJ mice. Arthritis and rheumatism 2013; 65: 660-670. DOI: 10.1002/art.37796

66. Diekman BO, Wu CL, Louer CR, Furman BD, Huebner JL, Kraus VB, Olson SA, Guilak F. Intra-articular delivery of purified mesenchymal stem cells from C57BL/6 or MRL/MpJ superhealer mice prevents posttraumatic arthritis. Cell Transplant 2013; 22: 1395-1408. DOI: $10.3727 / 096368912 \times 653264$

67. Mak J, Jablonski CL, Leonard CA, Dunn JF, Raharjo E, Matyas JR, Biernaskie J, Krawetz RJ. Intra-articular injection of synovial mesenchymal stem cells improves cartilage repair in a mouse injury model. Scientific reports 2016; 6: 23076. DOI: $10.1038 /$ srep23076

68. Seifer DR, Furman BD, Guilak F, Olson SA, Brooks SC, Kraus VB. Novel synovial fluid recovery method allows for quantification of a marker of arthritis in mice. Osteoarthritis and cartilage / OARS, Osteoarthritis Research Society 2008; 16: 1532 1538. DOI: 10.1016/j.joca.2008.04.013

69. Christiansen BA, Anderson MJ, Lee CA, Williams JC, Yik JH, Haudenschild DR. Musculoskeletal changes following non-invasive knee injury using a novel mouse model of post-traumatic osteoarthritis. Osteoarthritis and cartilage / OARS, Osteoarthritis Research Society 2012; 20: 773-782. DOI: 10.1016/j.joca.2012.04.014

70. Killian ML, Isaac DI, Haut RC, Déjardin LM, Leetun D, Donahue TL. Traumatic anterior cruciate ligament tear and its implications on meniscal degradation: a preliminary novel lapine osteoarthritis model. J Surg Res 2010; 164: 234-241. DOI: 10.1016/j.jss.2009.03.006

71. Poulet B, Hamilton RW, Shefelbine S, Pitsillides AA. Characterizing a novel and adjustable noninvasive murine joint loading model. Arthritis and rheumatism 2011; 63: 137-147. DOI: $10.1002 /$ art.27765 
72. Poulet B, Westerhof TA, Hamilton RW, Shefelbine SJ, Pitsillides AA. Spontaneous osteoarthritis in Str/ort mice is unlikely due to greater vulnerability to mechanical trauma. Osteoarthritis and cartilage / OARS, Osteoarthritis Research Society 2013; 21: 756-763. DOI: 10.1016/j.joca.2013.02.652

73. Onur TS, Wu R, Chu S, Chang W, Kim HT, Dang AB. Joint instability and cartilage compression in a mouse model of posttraumatic osteoarthritis. Journal of orthopaedic research : official publication of the Orthopaedic Research Society 2014; 32: 318323. DOI: $10.1002 /$ jor.22509

74. Wu P, Holguin N, Silva MJ, Fu M, Liao W, Sandell LJ. Early response of mouse joint tissue to noninvasive knee injury suggests treatment targets. Arthritis \& rheumatology 2014; 66: 1256-1265. DOI: 10.1002/art.38375

75. Steadman JR, Briggs KK, Rodrigo JJ, Kocher MS, Gill TJ, Rodkey WG. Outcomes of microfracture for traumatic chondral defects of the knee: average 11-year follow-up. Arthroscopy : the journal of arthroscopic \& related surgery : official publication of the Arthroscopy Association of North America and the International Arthroscopy Association 2003; 19: 477-484. DOI: 10.1053/jars.2003.50112

76. Steadman JR, Miller BS, Karas SG, Schlegel TF, Briggs KK, Hawkins RJ. The microfracture technique in the treatment of full-thickness chondral lesions of the knee in National Football League players. The journal of knee surgery 2003; 16: 83-86.

77. Mithoefer K, Williams RJ, 3rd, Warren RF, Potter HG, Spock CR, Jones EC, Wickiewicz TL, Marx RG. The microfracture technique for the treatment of articular cartilage lesions in the knee. A prospective cohort study. The Journal of bone and joint surgery American volume 2005; 87: 1911-1920. DOI: 10.2106/JBJS.D.02846

78. Montoya F, Martinez F, Garcia-Robles M, Balmaceda-Aguilera C, Koch X, Rodriguez F, Silva-Alvarez C, Salazar K, Ulloa V, Nualart F. Clinical and experimental approaches to knee cartilage lesion repair and mesenchymal stem cell chondrocyte differentiation. Biological research 2013; 46: 441-451. DOI: 10.4067/S0716-97602013000400015

79. Matsuoka M, Onodera T, Sasazawa F, Momma D, Baba R, Hontani K, Iwasaki N. An Articular Cartilage Repair Model in Common C57Bl/6 Mice. Tissue engineering Part C, Methods 2015; 21: 767-772. DOI: 10.1089/ten.TEC.2014.0440

80. Eltawil NM, De Bari C, Achan P, Pitzalis C, Dell'accio F. A novel in vivo murine model of cartilage regeneration. Age and strain-dependent outcome after joint surface injury. Osteoarthritis and cartilage / OARS, Osteoarthritis Research Society 2009; 17: 695-704. DOI: 10.1016/j.joca.2008.11.003

81. Fitzgerald J, Rich C, Burkhardt D, Allen J, Herzka AS, Little CB. Evidence for articular cartilage regeneration in $\mathrm{MRL} / \mathrm{MpJ}$ mice. Osteoarthritis and cartilage / OARS, Osteoarthritis Research Society 2008; 16: 1319-1326. DOI: 10.1016/j.joca.2008.03.014

82. Kench JA, Russell DM, Fadok VA, Young SK, Worthen GS, Jones-Carson J, Henson JE, Henson PM, Nemazee D. Aberrant wound healing and TGF-beta production in the autoimmune-prone MRL/+ mouse. Clin Immunol 1999; 92: 300-310. DOI: 10.1006/clim.1999.4754

83. Rajnoch C, Ferguson S, Metcalfe AD, Herrick SE, Willis HS, Ferguson MW. Regeneration of the ear after wounding in different mouse strains is dependent on the severity of wound trauma. Developmental dynamics : an official publication of the American Association of Anatomists 2003; 226: 388-397. DOI: 10.1002/dvdy.10242

84. Zhou F, He X, Iwakura Y, Horai R, Stuart JM. Arthritis in mice that are deficient in interleukin-1 receptor antagonist is dependent on genetic background. Arthritis and rheumatism 2005; 52: 3731-3738. DOI: 10.1002/art.21481 
85. Heydemann A. The super super-healing MRL mouse strain. Frontiers in biology 2012; 7: 522-538. DOI: 10.1007/s11515-012-1192-4

86. Li X, Gu W, Masinde G, Hamilton-Ulland M, Rundle CH, Mohan S, Baylink DJ. Genetic variation in bone-regenerative capacity among inbred strains of mice. Bone 2001; 29: 134-140.

87. Li X, Gu W, Masinde G, Hamilton-Ulland M, Xu S, Mohan S, Baylink DJ. Genetic control of the rate of wound healing in mice. Heredity 2001; 86: 668-674.

88. Manigrasso MB, O'Connor JP. Comparison of fracture healing among different inbred mouse strains. Calcified tissue international 2008; 82: 465-474. DOI: 10.1007/s00223-008-9144-3

89. Brittberg M, Lindahl A, Nilsson A, Ohlsson C, Isaksson O, Peterson L. Treatment of deep cartilage defects in the knee with autologous chondrocyte transplantation. The New England journal of medicine 1994; 331: 889-895. DOI: 10.1056/NEJM199410063311401

90. Behrens P, Bitter T, Kurz B, Russlies M. Matrix-associated autologous chondrocyte transplantation/implantation (MACT/MACI)--5-year follow-up. The Knee 2006; 13: 194-202. DOI: 10.1016/j.knee.2006.02.012

91. Rogers BA, David LA, Briggs TW. Sequential outcome following autologous chondrocyte implantation of the knee: a six-year follow-up. International orthopaedics 2010; 34: 959-964. DOI: 10.1007/s00264-009-0842-x

92. Beris AE, Lykissas MG, Kostas-Agnantis I, Manoudis GN. Treatment of fullthickness chondral defects of the knee with autologous chondrocyte implantation: a functional evaluation with long-term follow-up. The American journal of sports medicine 2012; 40: 562-567. DOI: 10.1177/0363546511428778

93. Filardo G, Kon E, Berruto M, Di Martino A, Patella S, Marcheggiani Muccioli GM, Zaffagnini S, Marcacci M. Arthroscopic second generation autologous chondrocytes implantation associated with bone grafting for the treatment of knee osteochondritis dissecans: Results at 6 years. The Knee 2012; 19: 658-663. DOI: 10.1016/j.knee.2011.08.007

94. Pelissier A, Boyer P, Boussetta Y, Bierry G, Van Hille W, Hamon P, Jaeger JH, Massin P. Satisfactory long-term MRI after autologous chondrocyte implantation at the knee. Knee surgery, sports traumatology, arthroscopy : official journal of the ESSKA 2014; 22: 2007-2012. DOI: 10.1007/s00167-013-2428-9

95. Bartlett W, Skinner JA, Gooding CR, Carrington RW, Flanagan AM, Briggs TW, Bentley G. Autologous chondrocyte implantation versus matrix-induced autologous chondrocyte implantation for osteochondral defects of the knee: a prospective, randomised study. The Journal of bone and joint surgery British volume 2005; 87: 640-645. DOI: 10.1302/0301-620X.87B5.15905

96. Cherubino P, Grassi FA, Bulgheroni P, Ronga M. Autologous chondrocyte implantation using a bilayer collagen membrane: a preliminary report. J Orthop Surg (Hong Kong) 2003; 11: 10-15.

97. Gigante A, Manzotti S, Bevilacqua C, Orciani M, Di Primio R, Mattioli-Belmonte M. Adult mesenchymal stem cells for bone and cartilage engineering: effect of scaffold materials. European journal of histochemistry : EJH 2008; 52: 169-174.

98. Trattnig S, Ba-Ssalamah A, Pinker K, Plank C, Vecsei V, Marlovits S. Matrix-based autologous chondrocyte implantation for cartilage repair: noninvasive monitoring by high-resolution magnetic resonance imaging. Magnetic resonance imaging 2005; 23: 779-787. DOI: 10.1016/j.mri.2005.04.010 
99. Zheng $\mathrm{MH}$, Willers $\mathrm{C}$, Kirilak L, Yates $\mathrm{P}, \mathrm{Xu}$ J, Wood D, Shimmin A. Matrixinduced autologous chondrocyte implantation (MACI): biological and histological assessment. Tissue engineering 2007; 13: 737-746. DOI: 10.1089/ten.2006.0246

100. Hwang NS, Zhang C, Hwang YS, Varghese S. Mesenchymal stem cell differentiation and roles in regenerative medicine. Wiley interdisciplinary reviews Systems biology and medicine 2009; 1: 97-106. DOI: 10.1002/wsbm.26

101. Kon E, Filardo G, Di Martino A, Marcacci M. ACI and MACI. The journal of knee surgery 2012; 25: 17-22.

102. Niethammer TR, Pietschmann MF, Horng A, Rossbach BP, Ficklscherer A, Jansson V, Muller PE. Graft hypertrophy of matrix-based autologous chondrocyte implantation: a two-year follow-up study of NOVOCART 3D implantation in the knee. Knee surgery, sports traumatology, arthroscopy : official journal of the ESSKA 2014; 22: 1329-1336. DOI: 10.1007/s00167-013-2454-7

103. Gardner OF, Archer CW, Alini M, Stoddart MJ. Chondrogenesis of mesenchymal stem cells for cartilage tissue engineering. Histology and histopathology 2013; 28: $23-$ 42.

104. Wang L, Tran I, Seshareddy K, Weiss ML, Detamore MS. A comparison of human bone marrow-derived mesenchymal stem cells and human umbilical cord-derived mesenchymal stromal cells for cartilage tissue engineering. Tissue engineering Part A 2009; 15: 2259-2266. DOI: 10.1089/ten.tea.2008.0393

105. van der Kraan PM, Buma P, van Kuppevelt T, van den Berg WB. Interaction of chondrocytes, extracellular matrix and growth factors: relevance for articular cartilage tissue engineering. Osteoarthritis and cartilage / OARS, Osteoarthritis Research Society 2002; 10: 631-637.

106. Handschel JG, Depprich RA, Kubler NR, Wiesmann HP, Ommerborn M, Meyer U. Prospects of micromass culture technology in tissue engineering. Head \& face medicine 2007; 3: 4. DOI: 10.1186/1746-160X-3-4

107. Bryant SJ, Anseth KS, Lee DA, Bader DL. Crosslinking density influences the morphology of chondrocytes photoencapsulated in PEG hydrogels during the application of compressive strain. Journal of orthopaedic research : official publication of the Orthopaedic Research Society 2004; 22: 1143-1149. DOI: 10.1016/j.orthres.2004.02.001

108. Liu X, Ma PX. Polymeric scaffolds for bone tissue engineering. Annals of biomedical engineering 2004; 32: 477-486.

109. Aufderheide AC, Athanasiou KA. Assessment of a bovine co-culture, scaffold-free method for growing meniscus-shaped constructs. Tissue engineering 2007; 13: 2195 2205. DOI: 10.1089/ten.2006.0291

110. Dehne T, Karlsson C, Ringe J, Sittinger M, Lindahl A. Chondrogenic differentiation potential of osteoarthritic chondrocytes and their possible use in matrix-associated autologous chondrocyte transplantation. Arthritis research \& therapy 2009; 11: R133. DOI: 10.1186/ar2800

111. Bouffi C, Thomas O, Bony C, Giteau A, Venier-Julienne MC, Jorgensen C, MonteroMenei C, Noel D. The role of pharmacologically active microcarriers releasing TGFbeta3 in cartilage formation in vivo by mesenchymal stem cells. Biomaterials 2010; 31: 6485-6493. DOI: 10.1016/j.biomaterials.2010.05.013

112. Morille M, Van-Thanh T, Garric X, Cayon J, Coudane J, Noel D, Venier-Julienne MC, Montero-Menei CN. New PLGA-P188-PLGA matrix enhances TGF-beta3 release from pharmacologically active microcarriers and promotes chondrogenesis of mesenchymal stem cells. Journal of controlled release : official journal of the Controlled Release Society 2013; 170: 99-110. DOI: 10.1016/j.jconrel.2013.04.017 
113. van Beuningen HM, van der Kraan PM, Arntz OJ, van den Berg WB. Transforming growth factor-beta 1 stimulates articular chondrocyte proteoglycan synthesis and induces osteophyte formation in the murine knee joint. Laboratory investigation; a journal of technical methods and pathology 1994; 71: 279-290.

114. Manferdini C, Maumus M, Gabusi E, Piacentini A, Filardo G, Peyrafitte JA, Jorgensen C, Bourin P, Fleury-Cappellesso S, Facchini A, Noel D, Lisignoli G. Adipose-derived mesenchymal stem cells exert antiinflammatory effects on chondrocytes and synoviocytes from osteoarthritis patients through prostaglandin E2. Arthritis and rheumatism 2013; 65: 1271-1281. DOI: 10.1002/art.37908

115. Murphy JM, Fink DJ, Hunziker EB, Barry FP. Stem cell therapy in a caprine model of osteoarthritis. Arthritis and rheumatism 2003; 48: 3464-3474. DOI: 10.1002/art.11365

116. ter Huurne M, Schelbergen R, Blattes R, Blom A, de Munter W, Grevers LC, Jeanson J, Noel D, Casteilla L, Jorgensen C, van den Berg W, van Lent PL. Antiinflammatory and chondroprotective effects of intraarticular injection of adipose-derived stem cells in experimental osteoarthritis. Arthritis and rheumatism 2012; 64: 3604-3613. DOI: 10.1002/art.34626

117. Horie M, Choi H, Lee RH, Reger RL, Ylostalo J, Muneta T, Sekiya I, Prockop DJ. Intra-articular injection of human mesenchymal stem cells (MSCs) promote rat meniscal regeneration by being activated to express Indian hedgehog that enhances expression of type II collagen. Osteoarthritis and cartilage / OARS, Osteoarthritis Research Society 2012; 20: 1197-1207. DOI: 10.1016/j.joca.2012.06.002

118. Singer NG, Caplan AI. Mesenchymal stem cells: mechanisms of inflammation. Annual review of pathology 2011; 6: 457-478. DOI: 10.1146/annurev-pathol-011110130230

119. Dell'Accio F, De Bari C, El Tawil NM, Barone F, Mitsiadis TA, O'Dowd J, Pitzalis C. Activation of WNT and BMP signaling in adult human articular cartilage following mechanical injury. Arthritis research \& therapy 2006; 8: R139. DOI: 10.1186/ar2029

120. Gruber J, Vincent TL, Hermansson M, Bolton M, Wait R, Saklatvala J. Induction of interleukin-1 in articular cartilage by explantation and cutting. Arthritis and rheumatism 2004; 50: 2539-2546. DOI: 10.1002/art.20369

121. Vincent T, Hermansson M, Bolton M, Wait R, Saklatvala J. Basic FGF mediates an immediate response of articular cartilage to mechanical injury. Proceedings of the National Academy of Sciences of the United States of America 2002; 99: 8259-8264. DOI: 10.1073/pnas.122033199

122. Stoop R, van der Kraan PM, Buma P, Hollander AP, Billinghurst RC, Poole AR, van den Berg WB. Type II collagen degradation in spontaneous osteoarthritis in C57B1/6 and BALB/c mice. Arthritis and rheumatism 1999; 42: 2381-2389. DOI: 10.1002/1529-0131(199911)42:11<2381::AID-ANR17>3.0.CO;2-E

123. Mahr S, Menard J, Krenn V, Muller B. Sexual dimorphism in the osteoarthritis of STR/ort mice may be linked to articular cytokines. Annals of the rheumatic diseases 2003; 62: 1234-1237.

124. Poulet B, de Souza R, Knights CB, Gentry C, Wilson AM, Bevan S, Chang YM, Pitsillides AA. Modifications of gait as predictors of natural osteoarthritis progression in STR/Ort mice. Arthritis \& rheumatology 2014; 66: 1832-1842. DOI: 10.1002/art.38616

125. Blom AB, van Lent PL, Libregts S, Holthuysen AE, van der Kraan PM, van Rooijen $\mathrm{N}$, van den Berg WB. Crucial role of macrophages in matrix metalloproteinasemediated cartilage destruction during experimental osteoarthritis: involvement of 
matrix metalloproteinase 3. Arthritis and rheumatism 2007; 56: 147-157. DOI: 10.1002/art.22337

126. van der Kraan PM, Vitters EL, van Beuningen HM, van de Putte LB, van den Berg WB. Degenerative knee joint lesions in mice after a single intra-articular collagenase injection. A new model of osteoarthritis. J Exp Pathol (Oxford) 1990; 71: 19-31.

127. van Osch GJ, van der Kraan PM, van Valburg AA, van den Berg WB. The relation between cartilage damage and osteophyte size in a murine model for osteoarthritis in the knee. Rheumatology international 1996; 16: 115-119.

128. van Osch GJ, van der Kraan PM, Vitters EL, Blankevoort L, van den Berg WB. Induction of osteoarthritis by intra-articular injection of collagenase in mice. Strain and sex related differences. Osteoarthritis and cartilage / OARS, Osteoarthritis Research Society 1993; 1: 171-177.

129. Visco DM, Orevillo CJ, Kammerman J, Kincaid SA, Widmer WR, Christen AJ. Progressive chronic osteoarthritis in a surgically induced model in mice. Trans Orthop Res Soc 1996; 21. 

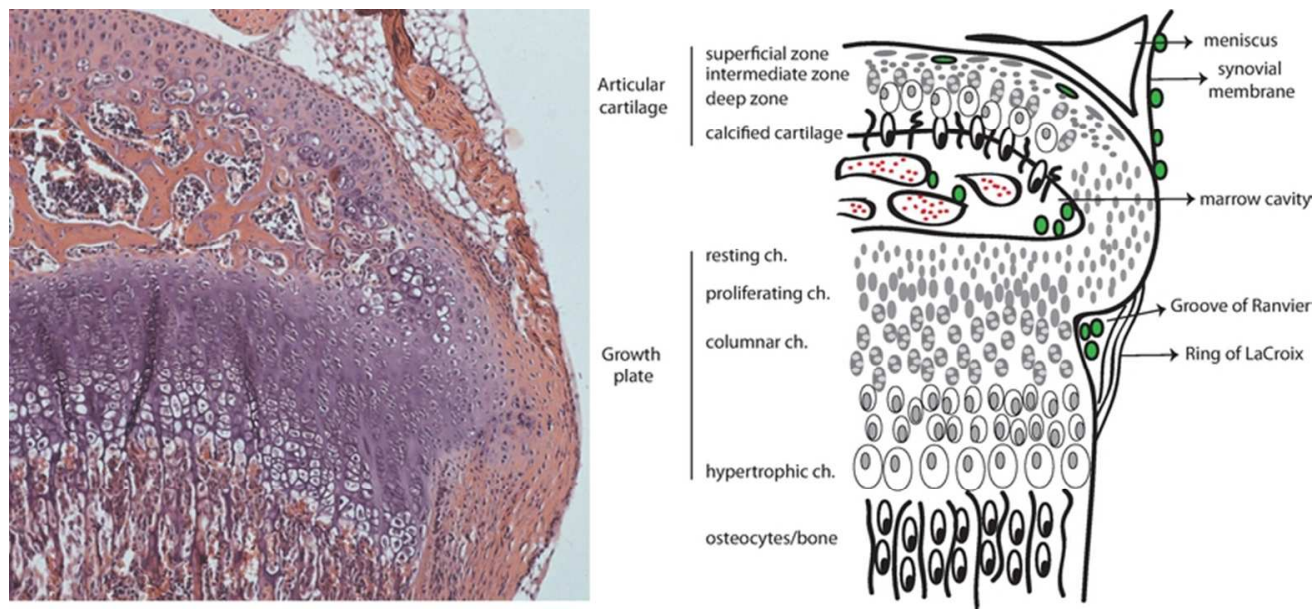

Figure 1. Schematic representation of stem cell niches identified in the knee joint. Stem cells are depicted in green. Pre-chondrogenic SCs have been identified between cells of the superficial zone ${ }^{98,99}$, in the groove of Ranvier ${ }^{107,108}$ and in the synovium ${ }^{102}$. Multilineage stromal stem cells have been isolated from bone marrow ${ }^{95-97}$.

$71 \times 33 \mathrm{~mm}(300 \times 300 \mathrm{DPI})$ 


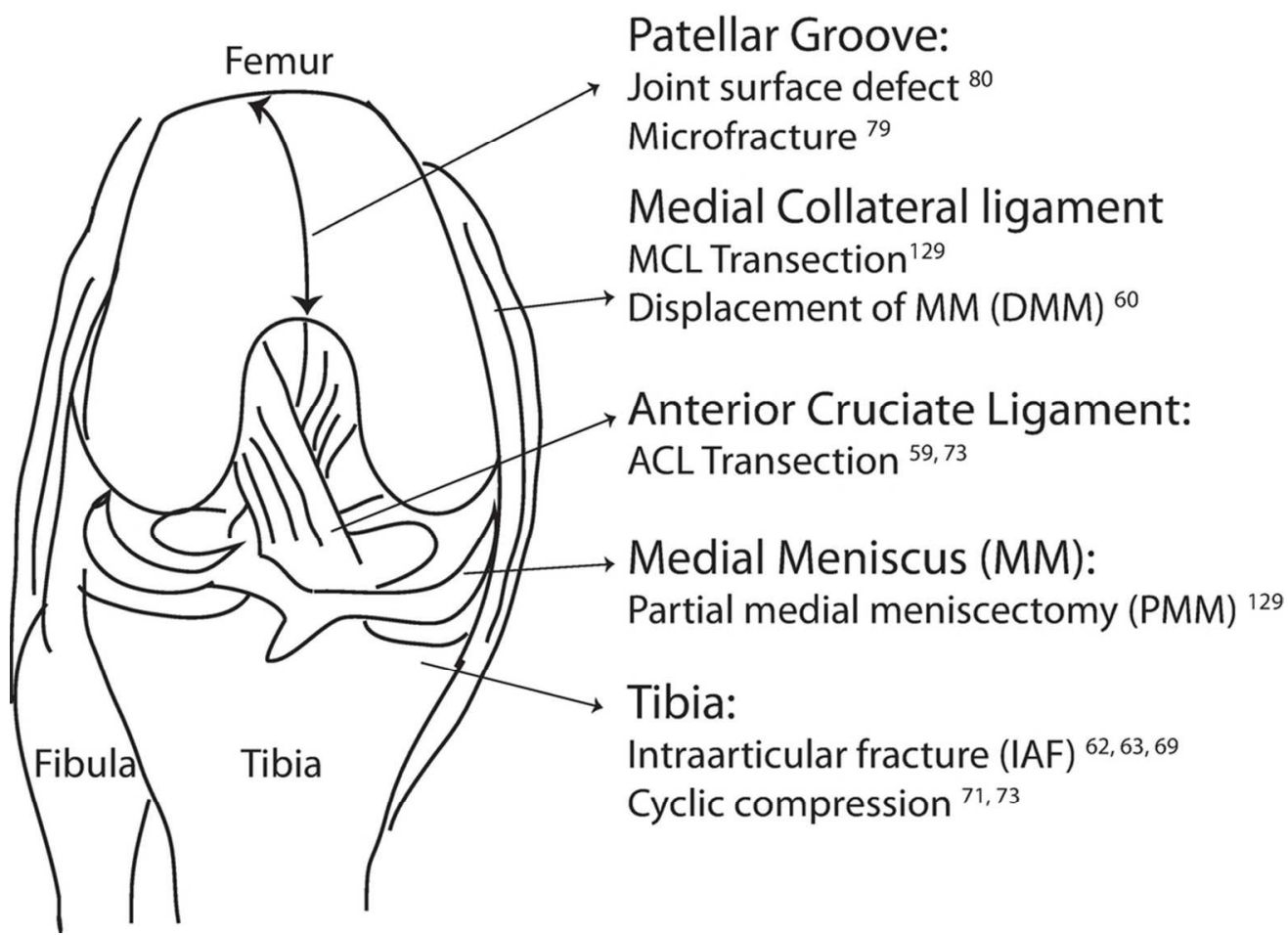

Figure 2. Schematic representation and location of different surgical model in the knee. Location of different surgical models and type of surgery to induce a cartilage defect are depicted. Severity of OA achieved with different techniques is reported in Table1. Patellar ligament and patella have been omitted for simplification purposes.

$93 \times 68 \mathrm{~mm}(300 \times 300$ DPI $)$ 
Table 1. Different technique to induce OA in small animal models

\begin{tabular}{|c|c|c|c|}
\hline Type of OA & Model & Severity of OA & References \\
\hline $\begin{array}{l}\text { Spontaneous/age- } \\
\text { induced }\end{array}$ & $\begin{array}{c}\mathrm{C} 57 \mathrm{Bl} / 6, \mathrm{Balb} / \mathrm{c} \text { and } \\
\text { STR/ort mouse } \\
\text { strains }\end{array}$ & $\begin{array}{l}\text { Similar to human: } \\
\text { males are more } \\
\text { severely affected } \\
\text { than females }\end{array}$ & $\begin{array}{l}\text { Mason et al., } 2001^{46} \text {; } \\
\text { Stoop et al., } 1999^{122} \text {; } \\
\text { Mahr et al., } 2003^{123}\end{array}$ \\
\hline $\begin{array}{l}\text { Stress/exercise } \\
\text { induced }\end{array}$ & Treadmill & Mild & Poulet et al., $2014^{124}$ \\
\hline Chemically induced & $\begin{array}{c}\text { Monosodium } \\
\text { iodoacetate, } \\
\text { collagenase intra- } \\
\text { articular injection }\end{array}$ & Acute and severe & $\begin{array}{l}\text { Blom et al., } 2007^{125} \text {; } \\
\text { van der Kraan et al., } \\
\text { 1990 }{ }^{126} \text {; van Osch et } \\
\text { al., } 1993,1996^{127,128}\end{array}$ \\
\hline \multirow[t]{2}{*}{ Surgically induced } & PMM, MCLT & Severe & Visco et al., $1996^{129}$ \\
\hline & DMM, ACLT & Mild to severe & $\begin{array}{c}\text { Kamekura et al., } \\
2005^{59} ; \text { Glasson et } \\
\text { al., } 2007^{60}\end{array}$ \\
\hline \multicolumn{4}{|l|}{ Mechanically induced } \\
\hline high-energy forces & ,IAF & Acute and severe & $\begin{array}{l}\text { Furman et al., } 2007^{62} \\
\text { Lewis et al., } 2001^{63} \text {, } \\
\text { Christiansen et al., } \\
2012^{69}\end{array}$ \\
\hline low-energy forces & $\begin{array}{l}\text { Cyclic tibial } \\
\text { compression }\end{array}$ & Mild & $\begin{array}{l}\text { Poulet et al., } 2011^{71} \text {, } \\
\text { Onur et al., 2014 }\end{array}$ \\
\hline $\begin{array}{l}\text { low and high-energy } \\
\text { forces }\end{array}$ & $\begin{array}{l}\text { Cyclic tibial } \\
\text { compression with } \\
\text { ACL rupture }\end{array}$ & Mild and Severe & Onur et al., $2014^{73}$ \\
\hline $\begin{array}{r}\mathrm{PMM}=\text { partial me } \\
\mathrm{DMM}=\mathrm{destabilization}\end{array}$ & $\begin{array}{l}\text { meniscectomy; MCI } \\
\text { he medial meniscus; } \\
\text { IAF = intraarti }\end{array}$ & $\begin{array}{l}\text { Medial collateral li } \\
\mathrm{LT}=\text { anterior cruci } \\
\text { ar fracture }\end{array}$ & $\begin{array}{l}\text { ment transection; } \\
\text { ligament transection; }\end{array}$ \\
\hline
\end{tabular}

